\title{
Cytogenetic and Teratological Effects of Mancozeb Pre Natal Exposure on Rats
}

\author{
V. L. Castro*; ; A. J. Tambasco; L. C. Paraíba and D. D. Tambasco \\ Embrapa Meio Ambiente, Ecotoxicology Laboratory, Rodovia SP-340, Km 127,5, 13820-000 - Jaguariúna - SP - \\ Brazil.
}

\begin{abstract}
Studies were conducted on the dam's fertility and pup viability, litter physical and motor development and chromosomal analysis with female rats exposed to different concentrations of mancozeb, at initial and organogenesis periods of pregnancy. The exposure did not interfere with the pregnant females or their estrous cycle but resulted in retarded physical development, with exception of the vaginal opening and tests descent; which were in advance. The litter body weight was not affected. The examination of swimming performance indicated an initial impairment and a posterior recovery. The observed chromosome damage in dams and pups was found to enhance with the fungicide's concentration. The results obtained led to the conclusion that even in the absence of maternal signs of toxicity, mancozeb could be related to some genetic damage and teratogenic risk to the population exposed.
\end{abstract}

Key words: Mancozeb, Rats, Postnatal development, Prenatal exposure, Genetic evaluation.

\section{INTRODUCTION}

The ethylenebisdithiocarbamates (EBDCs) maneb and zineb are among the most widely used fungicides in agriculture. They enter the organism mainly through the respiratory tract, skin and mucous membranes and the digestive tract and have as their final main metabolite ethylenethiourea (ETU; 14). ETU has been shown to be both embryotoxic and teratogenic $(3,16)$, and also may be present as impurity in these fungicides comercial formulations. It may be also some of the residues transformed into during food processing of crops (38).

It has been reported that several derivatives of $\mathrm{N}$-methylcarbamic acid, including mancozeb, could metabolically result in the corresponding $\mathrm{N}$-nitroso compounds. A large percentage of the $\mathrm{N}$-nitroso compounds are alkylating agents which can react with nucleic acids and other cellular molecules $(6,31)$ leading to a mutagenesis, clastogenesis and carcinogenesis. Recently, genetic alterations of a clastogenic type have been reported to be associated with a variety of human cancer and birth defects (22).
Although EBDCs posses low acute toxicity, some of them have been shown chronically to possess carcinogenic, mutagenic, goiterogenic, and teratogenic activities in animal tests $(4,9$, $11,12,20,21,26)$. It has been postulated that EBDCs inhibit thyroid peroxidase (TOP), via the formation of ETU. They can also adversely affect reproductive ability, such as spermatogenesis (10).

Genetic and mutagenic toxicity studies on mancozeb have produced mixed results. A dosedependent increase of chromosomal aberration frequency was found at concentrations of 4,10 , 20 and $40 \mu \mathrm{g} / \mathrm{ml}$ mancozeb when administered during the last $24 \mathrm{~h}$ in $72 \mathrm{~h}$ human blood cultures. Also, a dose-related clastogenic effects were found for the 2,5 and $5 \mu \mathrm{g} / \mathrm{g}$ b.w. doses of mancozeb when given to Wistar rats as a single injection (7). Some authors have found these effects only when the maternal toxicity was evident $(8,23)$. The Central Nervous System CNS is apparently highly sensitive to toxic effects of these compounds, since the administration of maneb during gestation can result in degenerative changes and hydrocephalus in the neonates $(16,17)$.

\footnotetext{
* Author for correspondence
} 
Behavioral alterations such as decreased learning ability, subsequent to dietary maneb administration in the pre - and postweanling rats have also been reported (34). Thus, the subchronic and chronic toxicity of them should not be ignored. Furthermore, the toxicological responses observed in a subchronic study may be quite different from those observed in an acute one; demanding further investigations in relation of functional, biochemical, physiological or pathological effects.

Examining the possible teratogenic effects of EBDCs in young animals may provide evidence regarding the underlying primary alterations associated with the substance especially because these effects could lead to secondary disruptions in the development of the neural systems that might alter the animals behavior in the adulthood. Both of these consequences may alter later development as the animal matures, making it difficult to tease apart the underlying primary alterations from the compensatory or secondary changes resulting from prenatal exposure to a compound, so the focus on early assessment was selected in this work. The aim of the present study was to examine the possible early developmental consequences of exposure to mancozeb during pregnancy in dams that have not showed apparent physical or behavioral abnormalities.

\section{MATERIALS AND METHODS}

\section{Animals maintenance}

Male and female Wistar rats (UNICAMP University of Campinas - Breeding Laboratory) weighing 180-230 $\mathrm{g}$ and about 80 days of age were used. The animals were housed in temperature controlled $\left(21-23^{\circ} \mathrm{C}\right)$ and artificially lighted rooms, on a $12 \mathrm{~h}$ light-dark cycle (lights on 7:00 a.m.) with free access to food and water.

The animals were adapted to the conditions of our animal quarters for 21 days before starting the experiment. The experiments were performed in a different room, where temperature was the same as in the animal colony.

\section{Chemicals and exposure}

Mancozeb [Dithane - 82,7\% pure (Rohm; Haas)] mixed into the diet (Purina Rodent Chow) at concentrations of 0,2000 or $3.000 \mathrm{ppm}$ was administered in the diet to primiparous female rats $(180-200 \mathrm{~g})$ randomly and equally divided into groups (10 each). The animals consumed feed containing mancozeb at different treatment groups : from day 1 of pregnancy (the day spermatozoa were detected in the female's vaginal smears) to day 6 of pregnancy (group A), or at $6^{\text {th }}$ from $15^{\text {th }}$ days of pregnancy (organogenesis phase - group B). Controls received only the vehicle in the same way. On day 1 of postnatal life, eight rat pups were left with each dam. The food consumed was monitored every day. Each dam ate about $20 \mathrm{~g}$ of food per day. Based on food consumption data, the animals ingested an equivalent of 30,0 $\mathrm{mg} / \mathrm{kg} / \mathrm{d}$ of dithane, resulting in estimated mancozeb daily intakes of $24,0 \mathrm{mg} / \mathrm{kg}$. The amount ingested was an approximate figure calculated using the formula (4): average food consumption (g) x dietary concentration (ppm)/ average body weight $(\mathrm{g})$.

\section{Viability of the pups and dams fertility evaluation}

The number of viable pups at birth and on the $21^{\text {st }}$ day of life and also the fertility of the dams were determined (Fisher exact test, 33). The pups were daily examined for viability and gross defects. One male was mated with two females in the estrous phase. After mating, the females were kept individually caged and were allowed to deliver. The dam's weight was also evaluated at interval between the $1^{\text {st }}$ and $21^{\text {st }}$ days of pregnancy (maternal weight gain). The dams were checked twice daily (9:00 and 17:00h) for parturition. Litters born after 17:00h were considered as day 0 of life the next day of observation.

The parameters tested were evaluated as \% fertility $\left(\mathrm{n}^{\circ}\right.$ of pregnant females $\mathrm{x} 100 / \mathrm{n}^{\circ}$ of mated females); birth viability ( $\mathrm{n}^{\mathrm{o}}$ of pups alive $\mathrm{x} 100 / \mathrm{n}^{\mathrm{o}}$ of total pups) and $21^{\text {st }}$ day viability $\left(\mathrm{n}^{\mathrm{o}}\right.$ pups alive at the end of lactation period x $100 /$ $\mathrm{n}^{\mathrm{o}}$ of total pups).

\section{Physical development evaluation}

Two pups of each dam were observed on the following developmental physical parameters to evaluate the possible effects of mancozeb exposure: pinna detachment (unfolding of 
external ear), development of fur, incisor teeth eruption, vaginal, ear and eye openings and tests descent. These time - percent effect curves were constructed using the percent of animals showing each of the above parameters and their time of appearance according their age (1). All pups were removed from the nest built for the dam with a paper towel and placed on a heating pad to provide warmth before and after testing. Each pup was examined before the next one. The order of testing the litters was determined by chance. For the analysis of significant deviations, the curves were compared by the Kolmogorov test (5). Body weights of all animals were taken at 1,10 and 21 days of life (Student's " $t$ " test, 33).

\section{Swimming test - neuromotor development evaluation}

For the swimming test, litters were used on postnatal days 7, 11 and 21. These rats were randomly used. An aquarium $(25 \times 30 \times 60 \mathrm{~cm})$, filled with water $\left(25^{\circ} \mathrm{C}\right)$ was used for the test between 10 to $12 \mathrm{~h}$. Each animal was dropped 3 times its own height into the center of the aquarium and was observed for $5 \mathrm{sec}$. Swimming performance was evaluated according to the position of the nose and head on the surface of the water to measure the motor development (36 - 24). After the test the animals were dried and returned to the home cage. The angle of swimming was rated as follows: 0 nose below surface; 1 - nose at or above surface; 2 - nose and top of head at or above surface but ears still below surface; 3 - same as 2 except with water line at midear level; 4 same as 3 except water line at bottom of ears.

\section{Bone marrow cells test}

The dams were tested after the lactation period (21 days) and litters at the 40 days of age. The animals were administered with colchicine $(0,20$ $\mathrm{ml} / 100 \mathrm{~g}-160 \mathrm{mg} / 100 \mathrm{ml}$ solution) one hour before the sacrifice.

Bone marrow cells were washed out from the femur using $0,075 \mathrm{M} \mathrm{KCL}$ solution. After 20 min. at $37^{\circ} \mathrm{C}$, the suspensions were centrifuged (10 min., $800 \mathrm{rpm}$ ) and the precipitates were fixed in methanol: acetic acid mixture (3:1) and centrifuged again under the same conditions as before. After fixation and centrifugation, the supernatants were discarded. The precipitate were removed to a frozen microscopic slide using a Pasteur pipette. After drying, the preparations were stained with Giemsa and examined for changes in the normal mitotic activity.

The number and type of chromosomal aberrations found in metaphasis for animal were scored until 100 cells per animal. Statistical analysis were made by SAS - PROC LIFETEST (32).

\section{Estrous cycle}

The females had their vaginal smears examined daily for 12 days after the 10 days mancozeb exposition. The phase of the estrous cycle for each one was observed. The number of each phase was compared between the groups by Student's t test (33).

\section{Statistical analysis}

The Bartlet's test for homocedasticity (13) was used to verify if data were parametric, since were employed the others statistical methods except the Mann-Whitney one. A probability of $\mathrm{p}<0,05$ was taken to show a significant difference between groups for all comparisons made.

\section{RESULTS}

Litter data and physical development of newborn

Mancozeb exposure did not alter the dam's fertility (number of pregnant females) nor their weight (Table 1)

Table 1. Effect of mancozeb exposure ( $\mathrm{I}=0 \mathrm{ppm}$; II $=2.000 \mathrm{ppm} ; \mathrm{III}=3.000 \mathrm{ppm})$ at different phases of the pregnancy $\left(\mathrm{A}-1^{\mathrm{st}}-6^{\text {th }} ; \mathrm{B}-6^{\text {th }}-21^{\mathrm{st}}\right.$ days) on the maternal weight gain $(\mathrm{g}, \mathrm{x} \pm \mathrm{SD})$ and on the percentage of the viability of pups and of the dam's fertility.

\begin{tabular}{|l|l|l|l|l|l|}
\hline \multicolumn{2}{|l|}{} & \multicolumn{2}{l|}{ Parameters } \\
\hline $\begin{array}{l}\text { Groups } \\
\text { and } \\
\text { Doses }\end{array}$ & $\begin{array}{l}\text { \% } \\
\text { Fertili } \\
\text { ty }\end{array}$ & $\begin{array}{l}\text { Dams } \\
\text { Weight (g) }\end{array}$ & $\begin{array}{l}\text { \% Birth } \\
\text { Viability }\end{array}$ & $\begin{array}{l}\text { Wean } \\
\text { Viability }\end{array}$ \\
\hline & & & & & \\
A & I & 80 & $55,86 \pm 3,06$ & 95 & 100 \\
A & II & 70 & $53,67 \pm 1,15$ & 100 & 100 \\
A & III & 80 & $51,25 \pm 2,34$ & 100 & 100 \\
B & I & 90 & $57,15 \pm 1,95$ & 95 & 100 \\
B & II & 80 & $55,18 \pm 2,17$ & 100 & 100 \\
B & III & 80 & $53,41 \pm 1,86$ & 85 & 100 \\
\hline
\end{tabular}

p > 0,05 - Fisher Exact Test

The mancozeb exposition resulted in retarded development of the pups, with exception of the 
vaginal open and descent tests, when occurred acceleration (Table 3). The litter body weight ratios were not affected (Table 2 ).

Table 2. Prenatal effects of mancozeb ( $\mathrm{I}=0 \mathrm{ppm}$; II $=2.000 \mathrm{ppm} ;$ III $=3.000 \mathrm{ppm}$ ) on the litter body weight ratios $(\mathrm{x} \pm \mathrm{SD}, \mathrm{g})$. The dams were treated at different phases of the pregnancy $\left(A-1^{\text {st }}-6^{\text {th }}\right.$; B $-6^{\text {th }}$ $21^{\text {st }}$ days).

\begin{tabular}{|llll|}
\hline $\begin{array}{l}\text { Days of } \\
\text { life }\end{array}$ & Doses & A & \multicolumn{2}{c|}{ Groups } \\
\hline $\mathbf{1}$ & I & $6,00 \pm 0,13$ & $6,00 \pm 0,13$ \\
& II & $5,79 \pm 0,20$ & $6,02 \pm 0,13$ \\
& III & $6,24 \pm 0,33$ & $6,03 \pm 0,16$ \\
$\mathbf{1 0}$ & I & $16,24 \pm 0,53$ & $16,27 \pm 0,89$ \\
& II & $15,21 \pm 1,23$ & $16,24 \pm 0,26$ \\
& III & $16,79 \pm 1,24$ & $14,62 \pm 0,54$ \\
$\mathbf{2 1}$ & I & $29,94 \pm 1,04$ & $29,94 \pm 1,04$ \\
& II & $28,72 \pm 1,63$ & $30,24 \pm 2,40$ \\
& III & $31,49 \pm 2,11$ & $30,62 \pm 2,27$ \\
\hline
\end{tabular}

$\mathrm{p}>0,05$ - Student t Test

Table 3. Prenatal effects of mancozeb ( $\mathrm{I}=0 \mathrm{ppm}$; II $=2.000 \mathrm{ppm} ; \quad$ III $=3.000 \mathrm{ppm}$ ) on the physical development of rats. The results are presented as the maximum frequency difference of the parameter appearance in the exposed animals in relation to control ones. The dams were treated at different phases of the pregnancy (A $-1^{\text {st }}-6^{\text {th }} ; \mathrm{B}-6^{\text {th }}-21^{\text {st }}$ days).

\begin{tabular}{|c|c|c|c|}
\hline \multirow{2}{*}{ Parameters } & \multirow{2}{*}{ Doses } & \multicolumn{2}{|c|}{ Groups } \\
\hline & & A & B \\
\hline \multirow{4}{*}{$\begin{array}{l}\text { Pinna } \\
\text { Detachment }\end{array}$} & II & 18,86 & 56,20 \\
\hline & & $(0,15)$ & $(0,00)^{*}$ \\
\hline & III & 100,00 & 78,43 \\
\hline & & $(0,00)^{*}$ & $(0,00)^{*}$ \\
\hline \multirow{4}{*}{$\begin{array}{l}\text { Development } \\
\text { Fur }\end{array}$} & II & 78,43 & 78,43 \\
\hline & & $(0,00)^{*}$ & $(0,00)^{*}$ \\
\hline & III & $28,96 *$ & $49,02 *$ \\
\hline & & $(0,01)^{*}$ & $(0,00)^{*}$ \\
\hline \multirow{3}{*}{$\begin{array}{l}\text { Incisor } \\
\text { Eruption }\end{array}$} & II & 22,16 & 37,25 \\
\hline & & $(0,07)$ & $(0,00)^{*}$ \\
\hline & III & $\begin{array}{l}37,25 \\
(0,00)^{*}\end{array}$ & $\begin{array}{l}78,43 \\
(0,00)^{*}\end{array}$ \\
\hline \multirow[t]{4}{*}{ Ear Opening } & II & 24,12 & 42,26 \\
\hline & & $(0,04)^{*}$ & $(0,00)^{*}$ \\
\hline & III & 39,21 & 60,78 \\
\hline & & $(0,00)^{*}$ & $(0,00)^{*}$ \\
\hline \multirow[t]{4}{*}{ Eye Opening } & II & 29,52 & 12,52 \\
\hline & & $(0,01)^{*}$ & $(0,43)$ \\
\hline & III & 25,53 & 23,52 \\
\hline & & $(0,04)$ & $(0,05)$ \\
\hline \multirow{4}{*}{$\begin{array}{l}\text { Vaginal } \\
\text { Opening }\end{array}$} & II & 75,00 & 75,00 \\
\hline & & $(0,00)^{*}$ & $(0,00)^{*}$ \\
\hline & III & 60,00 & 75,00 \\
\hline & & $(0,00)^{*}$ & $(0,00)^{*}$ \\
\hline \multirow[t]{3}{*}{ Tests Descent } & II & 100,00 & $100,00 *$ \\
\hline & III & 56,52 & $100.00(0.00)$ \\
\hline & & $(0,00)^{*}$ & \\
\hline
\end{tabular}

$* \mathrm{p}<0,05$ in relation to I - Kolmogorov Test
The administration of mancozeb neither changed the maternal weight gain, nor caused any overt signs of toxicity or gross alterations in the pups.

\section{Swimming performance}

Examination of swimming performance (Table 4) indicated that the mean swimming scores of pups from treated groups were significantly less than the control values on postnatal day 14 . On postnatal day 21, however, the performance were the same in all groups.

Table 4. Swimming performance of developing rats exposed prenatally to mancozeb ( $\mathrm{I}=0 \mathrm{ppm}$; II = $2.000 \mathrm{ppm} ; \quad$ III $=3.000 \mathrm{ppm})$. The results are expressed as median of scores according St.Omer; Mohammad (1987). The dams were treated at different phases of the pregnancy $\left(A-1^{\text {st }}-6^{\text {th }} ; B-6^{\text {th }}-\right.$ $21^{\text {st }}$ days).

\begin{tabular}{|l|l|l|l|l|}
\hline & & \multicolumn{3}{|c|}{ Days of Life } \\
\hline Groups & Doses & $\mathbf{7}$ & $\mathbf{1 4}$ & $\mathbf{2 1}$ \\
A & I & 0 & 4 & 4 \\
& II & 0 & 3 & 4 \\
B & III & 0 & 3 & 4 \\
& I & 0 & 4 & 4 \\
& II & 0 & 3 & 4 \\
& III & 0 & $2,5 *$ & 4 \\
\hline
\end{tabular}

\section{Bone marrow metaphasis data}

The data concerning changes in the normal mitotic activity are listed in Table 5. The aberrations observed consisted mainly in the appearance of polyploid cells, pulverized cells and breaks. There was a linear relationship between the dosage and the toxic effects in the experiment. During the organogenesis phase dams an linear increase in the number of cells occurred that were complete with broken (CWB), incomplete with broken (IWB), pulverized (PUL) and to pups an linear increase in the number of cells that were CWB, IWB, PUL and POL (polyploid). During the initial period of the pregnancy occurred an increased linear effect for CWB and IWB, linear decrescent for CFB for the dams and also an increased linear effect for CWB,IWB, PUL and POL for the pups. 
Table 5. Effects of mancozeb exposition ( $\mathrm{I}=0 \mathrm{ppm}$; II $=2.000 \mathrm{ppm}$; III $=3.000 \mathrm{ppm})$ on bone marrow cells of the dams (DA) and the pups (PU). The results are presented as mean number of cells (SAS - * - increased linear and ** decreased linear - $p<0,05)$ that was CWB - Complete with broken; CFB - Complete free of broken; IWB Incomplete with broken; IFB - Incomplete free of broken; PUL - Pulverized and POL - Polyploid. The dams were treated at different phases of the pregnancy (A $-1^{\text {st }}-6^{\text {th }} ; \mathrm{B}-6^{\text {th }}-21^{\text {st }}$ days). The number and type of chromosomal aberrations found in metaphasis for animal were scored until 100 cells per animal.

\begin{tabular}{|c|c|c|c|c|c|c|c|}
\hline Groups & Doses & CFB & CWB & IFB & IWB & PUL & POL \\
\hline A DA & I & 51,12 & 3,41 & 7,24 & 2,53 & 7,06 & 0,06 \\
\hline PU & & 32,41 & 2,91 & 5,73 & 1,27 & 5,98 & 0,16 \\
\hline A DA & II & $37,00 * *$ & $4,83 *$ & 5,67 & $1,33 *$ & 11,00 & 0,33 \\
\hline PU & & 23,00 & $4,25 *$ & 2,75 & $2,17 *$ & $9,92 *$ & $0,17 *$ \\
\hline A DA & III & $22,61 * *$ & $2,75 *$ & 6,80 & $7,43 *$ & 12,15 & 0,83 \\
\hline PU & & 32,67 & $7,92 *$ & 2,58 & $4,92 *$ & $22,92 *$ & $0,75 *$ \\
\hline B DA & I & 51,12 & 3,41 & 7,24 & 2,53 & 7,06 & 0,06 \\
\hline PU & & 32,41 & 2,91 & 5,73 & 1,27 & 5,98 & 0,16 \\
\hline B DA & II & 30,83 & $4,50 *$ & 4,33 & $2,17 *$ & $8,67 *$ & 0,00 \\
\hline PU & & 27,46 & $4,54 *$ & 2,62 & $3,31 *$ & $13,00 *$ & $0,46 *$ \\
\hline B DA & III & 25,60 & $4,00 *$ & 8,40 & $5,60 *$ & $15,80 *$ & 1,40 \\
\hline PU & & 45,90 & $10,14 *$ & 8,10 & $7,95 *$ & $19,24 *$ & $0,52 *$ \\
\hline
\end{tabular}

\section{Estrous cycle evaluation}

The comparison of the mancozeb exposed group to the control group never revealed any significant difference in any phase of the estrous cycle (Table 6).

Table 6. Evaluation of the estrous cycle in females exposed to mancozeb ( $\mathrm{I}=0 \mathrm{ppm}$; II $=2.000 \mathrm{ppm}$;

$\mathrm{III}=3.000 \mathrm{ppm})$ and treated at different phases of the pregnancy $\left(\mathrm{A}-1^{\text {st }}-6^{\text {th }} ; \mathrm{B}-6^{\text {th }}-21^{\text {st }}\right.$ days $)$. The

data are show as the mean frequency of the each cycle phase appearance. Student's t test - $\mathrm{p}>0,05$

\begin{tabular}{|l|c|c|c|c|}
\hline \multirow{3}{*}{ Doses } & \multicolumn{4}{|c|}{ Estrous Cycle Phase Days of Life } \\
\cline { 2 - 5 } I & Proestrous & Estrous & Metestrous & Diestrous \\
II & $3,05 \pm 0,05$ & $2,22 \pm 0,04$ & $2,63 \pm 0,06$ & $2,08 \pm 0,04$ \\
III & $2,75 \pm 0,06$ & $2,40 \pm 0,02$ & $2,50 \pm 0,07$ & $2,39 \pm 0,02$ \\
\hline
\end{tabular}

\section{DISCUSSION}

A major characteristic of embryonic-fetal development is the existence of critical periods of development. Exogenous chemicals can lead to congenital defects. These defects may range from embryolethality and anatomical defects to a large variety of more subtle morphological, biochemical and functional abnormalities (28). The most subtle genetic effects of contaminant exposure appear to lie in their disruption of developmental pathways.
The bone marrow cells test is a sensitive and reliable method for assessing the mutagenic potential of various chemical agents. From the results obtained, it appeared there was a possible damage on the genetic material of mancozeb exposed organisms. The frequency of chromosome aberrations observed in this work was associated with increased dosing and showed that mancozeb was mutagenic to cells of rats bone marrow. Pulverizations are often related with clastogenic chemicals but there is a need for more detailed analysis of the causation of the genetic alterations here observed.

Birth weight of newborn is associated with wellbeing of infant and mother. In this work, there was no maternal toxic observed alterations. Also, there was no alteration observed in the estrous cycle of mancozeb exposed females or even in the percentage of fertility that was at a normal percentage as showed in Table I. The absence of damage events in the pups viability and in the pups weight were in agreement with that and indicated a direct effect in the litter. In the present work, pups remained with their biological mother. It is recognized that this limits the ability to draw conclusions about the direct toxic effects of the tested substance on the fetal-placental unit; however, in this study it was a priority to optimize the chance of observing alterations in the offspring. Furthermore, the 
fostering procedure was not used because the complex maternal-pup relationship has not been fully understood and it is not known if the fostering manipulation is stressful for the pups and/or the foster dam and, most importantly, what impact this would have upon development and behavior of the offspring. In the future, the study of the pups development using a crossfostering experimental design to specifically examine the effects of maternal treatment on the litter's development and behavior will be useful.

Prenatal mancozeb administration resulted also in some developmental motor alterations. Swimming behavior in rats requires the smooth coordination of higher centers of the brain and the integration of a coordinated series of reflex responses and extensor-flexor reflexes. Several studies suggested that the brain catecholaminergic systems, especially some discrete regions of dopaminergic one, might be involved in the normal ontogeny of swimming (36). The subtle neurotoxic effect on swimming performance, observed in this study was transient and appeared only during the early preweaning period of rapid development of the brain. It could be possible that some neurochemical compensatory mechanism or recovery masked later these manifestations. Perhaps the young animals learn to compensate for early effects, evidencing the plasticity of the immature nervous system. Several research has led to the suggestion that sensorimotor dysfunction may underlie some of the regulatory deficits following neural damage. This observation is made even more interesting by the evidences that catecholaminergic systems are biochemically immature for preweanling rats (2).

It is clear from these studies that the gestational mancozeb exposition was able to disrupt postnatal development in rats. There were some physical developmental delay induced by mancozeb administration. However, the parameters testes descent and vaginal opening were accelerated. They were also involved with the catecholaminergic system and LH/FSH released $(19,25,27,29,35)$. It was interesting to note that EBDC's could produce some alterations in this system $(18,37)$. Further studies may establish the involvement or otherwise this system in the preweaning mancozeb effects. The metabolism of mancozeb is known to involve at least two pathways leading to ETU. Thus, the effects attributable to mancozeb may result from in part of metabolic products. They are distributed among several maternal and embryos tissues $(30,15)$. Their mechanism of action, however, is not all elucidated.

Given the strong public concern of the potential role of xenobiotics mutagenesis and developmental defects, it is apparent that priority should be given to appraisal of the impacts of contaminant exposure on natural populations. These studies aim to protect populations to genetic damage from contaminant exposure.

\section{ACKNOWLEDGEMENTS}

This study was supported by FAPESP (92/07866) and CNPq (521044/93-6)

\section{RESUMO}

Foram realizados estudos abordando aspectos relativos a fertilidade, alterações cromossômicas e desenvolvimento da prole de ratas expostas ao fungicida mancozeb em diferentes períodos da prenhez.

A exposição não interferiu com a fertilidade ou o ciclo estral das fêmeas, mas ocasionou retardo no desenvolvimento físico dos filhotes, com exceção da descida dos testículos e abertura vaginal que sofreram adiantamento. $\mathrm{O}$ peso dos filhotes não foi alterado. $\mathrm{O}$ desempenho dos filhotes no teste de natação foi inicialmente prejudicado, mas posteriormente se eqüivaleu ao do grupo controle. Houve ainda alterações cromossômicas, diretamente proporcionais ao aumento da dose empregada.

Os resultados indicam que mesmo na ausência de sinais de toxicidade materna, o mancozeb pode estar relacionado a alterações genéticas e risco teratológico nas populações expostas. 


\section{REFERENCES}

Alder, S. (1983). Behavioral toxicology in ZBINDEN, G.; RACAGNI, G.; CUOMO, V.; WEISS, B. Application of Behavioral Pharmacology in Toxicology. New York, Raven Press, p.57-66.

Almli,C.; Fisher,R. (1977). Infant rats: sensorimotor ontogeny and effects of substantia nigra destruction, Brain Res. Bull., 2: 425 - 459.

Brocker, E. ; Schlatter, C. (1980). Dose dependence of the excretion of maneb metabolites in urine of rats. Toxicol. Lett. 6:221-224.

Chu, I.; Villeneuve, D. C.; Secours, V.; Valli, V.E. (1990). Toxicological assessment of chlorinated diphenyl ethers in the rat, Part II. J. Environ. Sci. Health, B25(2), 225-241.

Conover, W.J. (1980). Practical non parametric statistics. New York, John Wiley; Sons, p. 368-373.

Fishibein, L. (1979). Overview on potential mutagenic problems posed by some pesticides and their trace impurities. Environ. Health Perspect., 27:125-131.

Georgian, L.; Moraru, I.; Draghicescu, T.; Dinu, I.; Ghizelea, G. (1983). Citogenetic effects of alachlor and mancozeb, Mutat. Res., 116:341-348.

Giavini, E.; Vismara, C.; Broccia, M. (1983). Pre and post implantation embryotoxic effects of zinc dimethydithiocarbamate (Ziram) in the rat. Ecotoxicol. Environ. Saf., 7:531-537.

Graham, S.; Hansen, W.; Davis, F.; Perry, C. (1973). Effects of one-year administration of etlylenethiourea upon the thyroid of the rat. J. Agric. Food. Chem., 21:324-329.

Hemavathi, E.; Rahiman, M. (1993). Toxicological effects of ziram, thiram and dithane M-45 assessed by sperm shape abnormalities in mice. J. Toxicol. Environ. Health, 38:393-398.

Hirai, Y.; Kuwabara, N. (1990). Transplacentally induced anorectal malformations in rats. J. Pediatr. Surg., 25:812-816.

Israeli, R.; Sculsky, M.; Tiberin, P. (1983). Acute intoxication due to exposure to maneb and zineb. Scand J. Work. Environ. Health. 9:47-51.

Johnson, N.; Leone, F. (1974). Statistics and experimental dosing. In: Engineering and physical sciences, John Wiley, New York, p.241-244.

Jordan, L.; Neal, R. (1979). Examination of the in vivo metabolism of maneb and zineb to ethylenethiourea (ETU) in mice, Bull. Environ. Contam. Toxicol., 22 : 271 - 277.

Khera, K. (1987). Neuronal degeneration caused by ethylenethiourea in neuronal monocell layers in vitro and in fetal rat brain in vivo. Teratology, 36:87-93.

Khera, K. ; Tryphonas, S. (1977). Ethylenethiourea - induce hydrocephalus: pre-and postnatal pathogenesis in offspring from rats given a single oral dose during pregnancy. Toxicol. Appl. Pharmacol., 42:85-97.

Khera, L. ; Tryphonas, L. (1985). Nerve cell degeneration and progeny survival following ethylenethiourea treatment during pregnancy in rats. Neurotoxicology, 63:97102.

komulainen, H.; Savolainen, R. (1985). Effect of dithiocarbamate fungicides and thiurams on $\mathrm{H}^{3}$-haloperidol binding in rat brain. Arch.Toxicol. Suppl. 8:77-79.

Kyzer, J.S. ; Youngblood, W.W. (1978). Neurotransmitter systems and central neuroendocrine regulation. In: Phisychopharmacology: a Generations of Progress. New York, Raven Press. p.465486.

Laisi, A.; Tuominen, R.; Mannisto, P.; Savolainen, K.; Mattila, J. (1985). The effect of maneb, zineb and ethylenethiourea on the humoral activity of the pituitary thyroid axis in rat. Arch. Toxicol., Suppl., 8:253-258.

Lentza-Rizos, C. (1990). Ethylenethiourea (ETU) in relation to use of ethylenebisdithiocarbamate (EBDC) fungicides. Rev. Environ. Contam. Toxicol., 115:1-37.

Lin,M., Wu,C., Wang,T. (1987). Pesticide clastogenicity in chinese hamster ovary cells, Mutat. Res., 188: 241 - 250.

Lu, M.; Kennedy JR. G. (1986). Teratogenic evaluation of mancozeb in the rat following 
inhalation exposure, Toxicol. Appl. Pharmacol, 84: 355-368.

Mann, H. ; Whitney, D. (1947). On a test of wheterm one of two ramdom variables in stachastically larger than the other. Ann. Math. Statist. 18:50.

Maric, D.; Tadic, R.; Miline, R. (1974). The influence of the gonads on the functional development of the hypothalamo hypophyseal system of the male rat. Neuroendocrinology, 19: 92 - 98.

Marinovich, M.; Guizzetti, M.; Guilardi, F.; Viviani, B.; Corsini, E.; Galli, C. (1997). Thyroid peroxidase as toxicity target for dithiocarbamates. Arch. Toxicol., 71: 508 512.

McCann, S.M. ; Moss, R.L. (1975). Putative neurotransmitters involved in discharging gonadotrophin releasing neurohormones and the action of LH - Releasing hormone on the CNS. Life Sci., 16:833-852.

Mitchell, C. L. (1982). Nervous system toxicology, Raven Press, New York.

Raunm, W.; McGivern, R.; Peterson, M.; Shryne, J. ; Gorski, R. (1990). Prenatal inhibition of hypothalamic sex steroid uptake by cocaine: effects on neurobehavioral sexual differentiation in male rats. Dev. Brain Res., 53:230-236.

Ruddick, J. ; Khera, R. (1975). Pattern of anomalies following single oral doses of ethylenethiourea to pregnant rats. Teratology, 12:277-282.

Saffhill, R.; Margison, G.; O'Connor, P. (1985). Mechanism of carcinogenesis induced by alkylanting agents. Biochim. Biophys. Acta, 823:111-145.
SAS PROC LIFETEST - SAS/Stat User's Guide. (1988). Release 6.03 Edition, Cary NC. SAS Institute Inc. p. 1028.

Siegel, S. (1956). Non parametric statistics for the Behavioral Sciences. New York, McGraw-Hill.

SOBOTKA, T.; BRODIE, R.; COOK, M. (1972). Behavioral and neuroendocrine effects in rats of postnatal exposure to low dietary levels of maneb. Dev. Psychobiol, 5:137-148.

STEGER, R. (1990). Testosterone replacement fails to reserve the adverse effects of streptozotocin - induced diabetes on sexual behavior in the male rat. Pharmacol. Biochem. Behav., 35:577-582.

ST. Omer, V. ; Mohammad, F. (1987). Ontogeny of swimming behavior and brain catecholamine turnover in rats prenatally exposed to a mixture of 2,4dichlorophenoxyacetic and 2, 4, 5trichlorophenoxyacetic acids. Neuropharmacology, 26:1351-1358.

Thuranszki, K.; Kiss, I.; Botos, M.; Szebeni, A. (1982). Effect of dithiocarbamate-type chemicals on the nervous system of rats. Arch Toxicol. Suppl., 5:125-128.

WHO - WORLD HEALTH ORGANIZATION. (1988). Dithiocarbamate pesticides, ethylenethiourea, and propylenethiourea: a general introduction, Environ. Health Criteria, 78: Geneva. 